\title{
Decision Support of Waste Management Expenditures Efficiency Assessment
}

\author{
Jana Soukopová ${ }^{1}$, Ivan Malý ${ }^{1}$, Jiří Hřebíček ${ }^{2}$, and Michal Struk ${ }^{1}$ \\ ${ }^{1}$ Masaryk University, Faculty of Economics and Administration, \\ Department of Public Economics, Brno, Czech Republic \\ \{soukopova, ivan\}@econ.muni.cz, struk@mail.muni.cz \\ ${ }^{2}$ Masaryk University, Institute of Biostatistics and Analyses, Brno, Czech Republic \\ hrebicek@iba.muni.cz
}

\begin{abstract}
This paper is devoted to the development of methodology and information and communication technology tools for decision support in the public sector. It analyses appropriate metrics for a municipal solid waste management expenditure (MSWE) efficiency assessment using costeffectiveness Analysis (CEA). In addition to many other methodological issues, finding a proper output (performance, outcome) measurement is important. From the point of view of municipalities, such a measurement ought to be as clear and simple to use as possible. We analyse three possible criteria - total generated municipal solid waste, population, and municipality area - for evaluating MSWE efficiency in order to examine their appropriateness for municipal administration. The analysis covers three years, from 2009 to 2011, and municipalities from the South Moravian Region of the Czech Republic. We focus on a sample of 21 municipalities with specific administrative status. Expenditures were estimated using open public data from the Czech Ministry of Finance municipal accounts database. Correlation analysis showed a very strong relationship between the three chosen criteria. Public administration can certainly use all of the criteria for an efficiency assessment of MSWE to aid in decision making. However, the most suitable criterion to be population, since efficiency analysis results showed a strong correlation between population and both CEA for waste amount and CEA for municipality area. Moreover, population has a stronger relationship with MSWE than either of the other two criteria.
\end{abstract}

Keywords: cost-effectiveness analysis, municipal expenditures, efficiency, waste management, decision support, ICT, municipal solid waste.

\section{$1 \quad$ Introduction}

Defining and measuring the efficiency of environmental protection expenditures in the process of using public resources and their transformation into outputs and outcomes is an important issue of decision support in the public sector [22-23], [26]. Efficiency evaluation and its methodology and use of information and communication technology (ICT) tools have greatly improved and advanced in recent decades. 
However, efficiency evaluation still remains a conceptual challenge in relation to public expenditures. Although the amount of expenditures spent in a specific area is important, another key characteristic for decision support in public administration is (or should be) the efficiency of the spending. The efficiency affects the extent of a utility and the rate of satisfying people's needs. Efficiency can be perceived as a rational criterion for the actions of involved subjects and a key category of the economic approach for analysing and evaluating social processes [20], [34]. This economic rationality comes from the idea that rational action consists of the efficient use of limited resources for the purpose of maximizing goals or achieving desired use [34]. This is complicated by the fact that public sector outcomes (especially in environmental protection) are often off-market, lacking relevant data, and thus difficult to quantify, as stated by a collective group at the European Commission [21]. In such cases, cost-effective Analysis (CEA) appears to be the most useful tool for efficiency assessment [5], [19]. Quite a few studies dealing with this topic have been published in economic journals. A CEA of environmental protection expenditures was examined by [1], [9-11], [24], [28], [32-33]. A CEA for the centralized waste treatment industry was discussed in [9], [11] and [32]. Anderson [1] conducted a CEA of proposed effluent limitations and standards for industrial waste combustors [10] focused on remediation. Papageorgiou, Barton and Karagiannidis [24] focused on the impact of technologies used for energy recovery from municipal waste. Market structure and refuse collection of municipal waste was studied in [28]. Willan and Briggs [33] compared the results of relevant CEA studies.

Studies [7], [22-23], [27], [29-30] dealing with issue of efficiency in the field of waste management in the Czech Republic and Slovakia have been focused on contractual issues and on the impact of competitiveness on efficiency [27]. Data envelopment analysis for evaluating MSWE was used in [7] and [23]. We developed a simple model for calculating an ideal amount of municipal solid waste expenditures [29] based on the characteristics of the municipality.

Municipal solid waste management costs (and consequently the expenditures (MSWE) that are at the centre of our concern) are determined by numerous variables. There is extensive literature dealing with this issue, including [1], [11-12], [17-18], [24], [27]. The following variables have the largest impact:

- total generated solid municipal waste [t];

- population [number of inhabitants];

- area of municipality $\left[\mathrm{km}^{2}\right]$;

- distance from the municipality to the waste facility site $[\mathrm{km}]$;

- competitive environment;

- ownership type of collecting company (private, public);

- size of household;

- impact of income;

- other socioeconomic variables.

Given this number of variables, it could be quite costly to obtain the information needed for a serious efficiency assessment for public administration bodies such as municipalities. It is necessary to decide how much and what type of information is 
worth gathering [26]. Even a simple comparison in order to obtain a benchmark could be complicated. However, municipality representatives cannot conduct a complicated and sophisticated analysis on a daily basis in order to understand if they are doing well with their budgets and receiving good value for their money. A simple and robust efficiency assessment tool is needed to support their decision making.

There is a wide range of indicators for measuring output in waste management and in any other infrastructure service, as well as for measuring outcomes (defined as the impact of a service on its recipients [26] - for example, the impact of solid waste collection on environment protection). Esfahani [26] offers more than ten "performance measures" for sanitation infrastructure; some of them can be easily adapted to waste management.

We analyse a) amount of solid waste; b) population; and c) municipal area as criteria for "effectiveness measures" [26] in a CEA evaluating MSWE efficiency, in order to examine the use of these criteria for municipalities. The analysis covers three years, from 2009 to 2011, and the selected analysed sample consists of all the municipalities from the South Moravian Region of the Czech Republic. We focus on 21 municipalities with specific administrative status. Expenditures were estimated using open government data from the Czech Ministry of Finance municipal accounts database [2], [31]. The aim of this paper is to create a methodology and ICT tools for decision support of municipality decision makers enabling benchmarking with other municipalities.

\section{Methods and Data for Decision Support}

We chose cost-effectiveness analysis (CEA) as a simple metric for evaluating MSWE efficiency in public sector decision support. We intended to find the simplest method for considering and evaluating select criteria $c_{i j}, i=1, \ldots, k$ for $j$-municipality of a set of $n$ municipalities of a given region.

The basic algorithm for decision support in MSWE efficiency consists of the following steps:

1. collecting the set of MSWE data $\boldsymbol{e}=\left\{e_{1}, e_{2} \ldots, e_{n}\right\}$ from linked open data, where $n$ is the number of considered municipalities;

2. setting the matrix $C$ of selected criteria $\left\{c_{i j}\right\}, i=1 \ldots k, j=1 \ldots n$ for the evaluation of cost-effectiveness of MSWE in $n$ municipalities;

3. collecting data of criteria $c_{i j}, i=1 \ldots k, j=1 \ldots n$ from linked open data;

4. calculating the ratios $\mathrm{CEA}_{i j}=e_{j} / c_{i j}, i=1 \ldots k, j=1 \ldots n$ for each individual criterion $c_{i j}$ and each municipality expenditure $e_{j}$;

5. trimming values (reducing extreme values within samples) by chosen statistical tests;

6. comparing $\mathrm{CEA}_{i j}$ results in analysed samples of $n$ municipalities;

7. choosing individual criteria $c_{m j}$ in CEA $m$ from $\{1,2, \ldots, k\}$, for $j=1 \ldots n$ and their utilization. 
The above algorithm for decision support in evaluating MSWE efficiency was implemented in Maple [8], [13] connected with MS Excel. We analyse current MSWE $e_{j}, j=1 \ldots n$. The idea behind CEA is either minimizing $\mathrm{CEA}_{i j}$ i.e. $e_{j} / c_{i j}$ ratio or maximizing $1 / \mathrm{CEA}_{i j}$, i.e. $c_{i j} / e_{j}$ ratio, for $i=1, . ., k, j=1, \ldots, n$.

The most efficient municipality administration of the given region is then considered as the administration that attains either the lowest $e_{j} / c_{i j}$ ratio or the highest $c_{i j} / e_{j}$ ratio [19].

When we use the $e_{j} / c_{i j}$ ratio, the cost-effectiveness of a given expenditure can be expressed as follows:

$$
\min \left\{\mathrm{CEA}_{i j}\right\}
$$

There are several sources of linked open data in the above algorithm: municipal area and population were taken from the Czech Statistical Office (CZSO); amount of generated municipal solid waste was taken from the information system of the waste management database [16] provided by CENIA (Czech Environmental Information Agency): and MSWE were downloaded from the Czech Ministry of Finance's ARIS [2] and ÚFIS [31] databases. CZSO publishes a MSWE database as well, however, these linked open data are published only for larger administrative municipality units and are not exactly those we need. Such slight differences among data provided by CZSO and the Ministry of Finance in terms of expenditures have been noted by [3] and are most likely results of either incorrect reporting or differences in methodology.

Our sample from all of the municipalities of the Czech Republic consists of 672 municipalities $^{1}$ from the South Moravian Region (SMR) of the Czech Republic. We analysed municipalities in the whole SMR, and then conducted a more detailed analyses on a selected sample of 21 municipalities with specific administrative status usually abbreviated as ORPs. These municipalities are former county administrative capitals and represent over $50 \%$ of total population of the SMR.

\section{Outcomes and Discussion}

We chose the following three criteria for the CEA:

- $c_{1 j}$ - total generated solid municipal waste $[\mathrm{t}]$ for the first $\mathrm{CEA}_{1}$,

- $c_{2 j}$ - population for the second $\mathrm{CEA}_{2}$ [number of inhabitants]

$c_{3 j}-$ area of municipality $\left[\mathrm{km}^{2}\right]$ for the third $\mathrm{CEA}_{3} \mathrm{We}$ next calculated the individual $\mathrm{CEA}_{i j}$ for a selected sample of municipalities. We used data trimming [16] to reduce the original sample to an appropriate size. The following table contains the calculated ratios for municipalities of the SMR.

\footnotetext{
${ }^{1}$ The South Moravian Region officially has 673 municipalities. One of them, Březina, is a former military area that still operates under a special regime and has only a few permanent residents. We did not include it in our analysis. Some municipalities did not report certain characteristics, and are thus not included in sample for certain analyses.
} 
Table 1. Results of CEA for all municipalities from the South Moravian Region

\begin{tabular}{lccccccccc}
\hline & \multicolumn{3}{c}{$\mathrm{CEA}_{1}$} & \multicolumn{3}{c}{$\mathrm{CEA}_{2}$} \\
\hline Year & 2009 & 2010 & 2011 & 2009 & 2010 & 2011 & 2009 & 2010 & 2011 \\
Sample & 595 & 602 & 542 & 672 & 672 & 672 & 672 & 672 & 672 \\
siz $n$ & & & & & & & \\
mean & 3126.6 & 2779.4 & 93376.1 & 565.9 & 578.5 & 577.2 & 59044.2 & 61071.5 & 60986.2 \\
$\sigma$ & 10993.5 & 3282.0 & 1737375 & 258.0 & 257.4 & 258.9 & 103130.8 & 102731.2 & 100421.6 \\
$\gamma_{2}$ & 515.3 & 460.6 & 517.8 & 70.7 & 55.2 & 58.9 & 151.5 & 96.9 & 92.6 \\
$\gamma_{1}$ & 22.2 & 20.3 & 22.6 & 6.5 & 5.7 & 5.9 & 10.5 & 8.6 & 8.4 \\
$\operatorname{mean}_{(0.05)}$ & 2526.6 & 2587.2 & 2740.5 & 546.5 & 559.7 & 557.8 & 49115.4 & 50576.2 & 50665.6 \\
$\sigma_{(0.05)}$ & 749.8 & 678.8 & 951.0 & 132.5 & 140.1 & 139.1 & 40479.2 & 41475.4 & 41737.6 \\
$\gamma_{2(0.05)}$ & 0.9 & 0.0 & 9.4 & 0.2 & 0.5 & 0.3 & 5.8 & 5.7 & 6.0 \\
$\gamma_{1(0.05)}$ & 0.8 & 0.5 & 2.3 & 0.7 & 0.8 & 0.8 & 2.2 & 2.2 & 2.3 \\
\hline
\end{tabular}

Source: Authors $* \sigma$ - standard deviation, $\gamma_{2}-$ kurtosis, $\gamma_{1}-$ skewness, $(0.05)-5 \%$ trimmed sample

When considering $c_{1 j}$ criterion, we can see that $\mathrm{CEA}_{1}$ values show significant differences, especially in $2011^{2}$. We used data trimming methods [33] to provide results for a 5\% trimmed sample, using Maple [13] for the whole SMR. The following table contains calculated ratios $\mathrm{CEA}_{i}, i=1,2,3$ for 21 ORPs of the SMR.

Table 2. Results of CEA for 21 ORPs from the South Moravian Region

\begin{tabular}{|c|c|c|c|c|c|c|c|c|c|}
\hline & & $\mathrm{CEA}_{1}$ & & & $\mathrm{CEA}_{2}$ & & & $\mathrm{CEA}_{3}$ & \\
\hline Year & 2009 & 2010 & 2011 & 2009 & 2010 & 2011 & 2009 & 2010 & 2011 \\
\hline $\begin{array}{l}\text { Sample } \\
\text { size } n\end{array}$ & 21 & 21 & 21 & 21 & 21 & 21 & 21 & 21 & 21 \\
\hline mean & 2836.3 & 3006.3 & 3109.9 & 673.1 & 683.4 & 681.9 & 318123.2 & 315086.3 & 308977.9 \\
\hline$\sigma$ & 1081.0 & 1222.4 & 1106.1 & 209.0 & 219.7 & 197.5 & 353421.2 & 294602.2 & 270815.1 \\
\hline$\gamma_{2}$ & 2.4 & 3.7 & 1.5 & 4.8 & 4.6 & 5.7 & 16.6 & 11.1 & 11.9 \\
\hline$\gamma_{1}$ & 0.1 & 0.7 & -0.5 & -1.1 & -0.5 & -1.6 & 3.9 & 3.1 & 3.1 \\
\hline $\operatorname{mean}_{(0.1)}{ }^{*}$ & 2841.6 & 2971.9 & 3168.7 & 684.6 & 690.0 & 700.9 & 255775.4 & 271115.9 & 268670.5 \\
\hline$\sigma_{(0.1)}{ }^{*}$ & 689.2 & 700.4 & 803.4 & 115.8 & 116.1 & 116.7 & 257434.8 & 247240.9 & 258790.1 \\
\hline$\gamma_{2(0.1)}{ }^{*}$ & 0.2 & 0.1 & -0.8 & -0.2 & 0.3 & 0.0 & 0.4 & 5.2 & 1.1 \\
\hline$\gamma_{1(0.1)}{ }^{*}$ & 0.6 & 1.0 & 0.7 & 0.4 & 0.9 & 0.9 & 0.4 & 1.8 & 1.0 \\
\hline
\end{tabular}

Source: Authors $*_{\sigma}$-standard deviation, $\gamma_{2}-$ kurtosis, $\gamma_{1}-$ skewness, $(0,1)-10 \%$ trimmed sample

Table 2 shows that the presented data do not have a high value of standard deviation. We calculated results for a $5 \%$ trimmed sample of ORPs as in Table 1; however, due to the low number of municipalities the results were not different from the original sample. We also analysed values for a $10 \%$ trimmed sample. Even this adjusted sample did not show significant differences in results. Therefore we used the original sample of 21 ORPs for further analyses. We compared the calculated values

${ }^{2}$ The extreme values of mean and $\sigma$ in $2011\left(\mathrm{CEA}_{1}\right)$ are mainly due to the municipalities Zbýšov and Telnice, both of which have a population of around 600 and relatively high MSWE, reporting just 60 and $150 \mathrm{~kg}$ of collected municipal solid waste. This resulted in extreme CEA $i j$ ratios that affect the mean of the whole sample. 
among selected municipalities. We assume that $\mathrm{CEA}_{i}$ results for criteria $c_{1 j}, c_{2 j}$ and $c_{3 j}$ $j=1, . ., n$ will not differ significantly among $n$ municipalities, and thus they can be used for MSWE efficiency evaluation. The strength of the relationship between calculated criteria $\mathbf{c}_{i}=\left(c_{i 1}, \ldots, c_{i n}\right)$ is shown in the following table, with $\boldsymbol{c}_{1}$ and $\boldsymbol{c}_{2}$ having strongest relationship.

Table 3. Correlation coefficients between analysed criteria for different municipality samples

\begin{tabular}{lccccccccc}
\hline & \multicolumn{3}{c}{$\boldsymbol{c}_{1} \& \boldsymbol{c}_{2}$} & \multicolumn{3}{c}{$\boldsymbol{c}_{1} \& \boldsymbol{c}_{3}$} & \multicolumn{3}{c}{$\boldsymbol{c}_{2} \& \boldsymbol{c}_{3}$} \\
\hline Year & 2009 & 2010 & 2011 & 2009 & 2010 & 2011 & 2009 & 2010 & 2011 \\
SMR & 0.9979 & 0.9972 & 0.9990 & 0.8096 & 0.8061 & 0.8026 & 0.7781 & 0.7767 & 0.7767 \\
ORPs & 0.9987 & 0.9981 & 0.9997 & 0.9475 & 0.9498 & 0.9417 & 0.9384 & 0.9379 & 0.9378 \\
\hline
\end{tabular}

Source: Authors

The following table contains comparison between $\mathrm{CEA}_{i}$ results for all three variables in 2009-2011 for a 5\% trimmed sample of municipalities from the SMR and then for all 21 ORPs of the SMR.

Table 4. Correlation coefficients between $\mathrm{CEA}_{i}$ for different municipality samples

\begin{tabular}{lccccccccc}
\hline & \multicolumn{3}{c}{$\mathrm{CEA}_{1} \& \mathrm{CEA}_{2}$} & \multicolumn{3}{c}{$\mathrm{CEA}_{1} \& \mathrm{CEA}_{3}$} & \multicolumn{3}{c}{$\mathrm{CEA}_{2} \& \mathrm{CEA}_{3}$} \\
\hline Year & 2009 & 2010 & 2011 & 2009 & 2010 & 2011 & 2009 & 2010 & 2011 \\
SMR & 0.4224 & 0.4379 & 0.4473 & 0.0603 & 0.0102 & 0.0852 & 0.2102 & 0.1868 & 0.1647 \\
ORPs & 0.8185 & 0.8764 & 0.9140 & 0.7025 & 0.6205 & 0.5144 & 0.6055 & 0.5124 & 0.4112 \\
\hline
\end{tabular}

Source: Authors

Table 4 shows that $\mathrm{CEA}_{i}$ results for the variables of solid waste amount and population are significantly similar, especially in the ORPs. Moreover, in the ORPs all three criteria can be used, as correlations between $\mathrm{CEA}_{i}$ acquire significant values. For this reason, we tested $\mathrm{CEA}_{i}$ rankings for individual $i$-criteria among ORPs to see whether there were significant differences among them. The average rankings and standard deviations of rankings between 2009 and 2011 are presented in Table 5.

Table 5 shows that municipalities acquire relatively stable positions if comparing efficiency in individual categories among the sample. To verify whether municipalities acquire similar positions in individual efficiency categories, we calculated standard deviations of differences among the positions that municipalities acquired in different categories. The majority of municipalities acquired positions in individual years that vary only by one or two positions. Larger standard deviations were rather rare. Municipalities acquired very close positions especially in $\mathrm{CEA}_{3}$, where the largest standard deviation was 1.7 and the sum of standard deviations for 21 ORPs was only 15.3. 
Table 5. CEA average ranking among ORPs and standard deviations of rankings in years

\begin{tabular}{lcccccc}
\hline \multicolumn{1}{c}{ Municipality } & \multicolumn{2}{c}{ CEA $_{1}$} & \multicolumn{2}{c}{ CEA $_{2}$} & \multicolumn{3}{c}{$\mathrm{CEA}_{3}$} \\
\hline Brno & 20 & 0.8 & 19 & 1.6 & 21 & 0.0 \\
Znojmo & 20 & 0.8 & 20 & 1.2 & 19 & 0.5 \\
Hodonín & 11 & 1.7 & 15 & 2.2 & 15 & 0.8 \\
Břeclav & $\mathbf{7}$ & $\mathbf{4 . 1}$ & $\mathbf{1 6}$ & $\mathbf{0 . 5}$ & 10 & 0.5 \\
Vyškov & 9 & 4.2 & 5 & 2.5 & 10 & 1.7 \\
Blansko & 17 & 0.5 & 14 & 0.9 & 17 & 0.5 \\
Veselí n. M & 8 & 0.5 & 10 & 0.5 & 7 & 0.5 \\
Kyjov & 2 & 0.5 & 4 & 2.4 & 8 & 1.2 \\
Boskovice & 12 & 1.2 & 10 & 1.7 & 12 & 0.9 \\
Kuřim & 5 & 1.4 & 4 & 1.9 & 17 & 0.8 \\
Ivančice & 15 & 1.7 & 17 & 1.2 & 5 & 0.8 \\
Tišnov & 6 & 1.9 & 10 & 3.6 & 16 & 1.2 \\
Mikulov & 17 & 0.9 & 20 & 0.5 & 5 & 0.8 \\
Šlapanice & 5 & 0.8 & 6 & 0.5 & 14 & 0.8 \\
Bučovice & 10 & 0.9 & 12 & 2.1 & 3 & 0.0 \\
Slavkov u Brna & $\mathbf{1 7}$ & $\mathbf{1 . 7}$ & $\mathbf{4}$ & $\mathbf{0 . 8}$ & 10 & 1.2 \\
Moravský Krumlov & 1 & 0.0 & 1 & 0.0 & 1 & 0.0 \\
Hustopeče & 11 & 5.4 & 12 & 2.6 & 5 & 1.2 \\
Rosice & 10 & 2.1 & 6 & 3.3 & 12 & 1.2 \\
Pohořelice & 8 & 3.3 & 8 & 0.8 & 2 & 0.0 \\
Židlochovice & 20 & 1.2 & 18 & 2.9 & 20 & 0.5 \\
\hline Source Autry & & & & & &
\end{tabular}

Source: Authors

The observation that the results are closest between $\mathrm{CEA}_{1}$ and $\mathrm{CEA}_{2}$ was further verified by correlation analysis (see Table 5). Average rankings for the majority of municipalities did not differ by more than 3 positions. In the ORPs, Hodonín, Tišnov, and Rosice municipalities differed by 4 , resulting in a standard deviation value of around 2. We can see significant differences in rankings only in the ORPs Břeclav (9 positions) and Slavkov u Brna (13 positions $)^{3}$. These two municipalities acquired more similar results between $\mathrm{CEA}_{2}$ and $\mathrm{CEA}_{3}$. For this reason, we examined the relationships of individual criteria and MSWE.

Table 6. Correlation coefficients between analysed criteria and MSWE for different municipality samples

\begin{tabular}{lccccccccc}
\hline & \multicolumn{3}{c}{$\boldsymbol{e} \& \boldsymbol{c}_{1}$} & \multicolumn{3}{c}{$\boldsymbol{e} \& \boldsymbol{c}_{2}$} & \multicolumn{3}{c}{$\boldsymbol{e} \& \boldsymbol{c}_{3}$} \\
\hline Year & 2009 & 2010 & 2010 & 2009 & 2010 & 2011 & 2009 & 2010 & 2011 \\
SMR & 0.9128 & 0.8900 & 0.9237 & 0.9232 & 0.8775 & 0.9583 & 0.5077 & 0.5062 & 0.5050 \\
ORPs & 0.9128 & 0.8959 & 0.9731 & 0.9626 & 0.9087 & 0.9767 & 0.7957 & 0.7980 & 0.7773 \\
\hline
\end{tabular}

Source: Authors

\footnotetext{
${ }^{3}$ Bold values in Table 5 .
} 
Correlation analysis shows that municipalities can use all three examined criteria for MSWE efficiency evaluation. Nevertheless, based on Tables 4, 5, and 6 we suggest that the most suitable criterion for CEA evaluation is $c_{2}-$ population. Population has strongest correlation with MSWE. The results of $\mathrm{CEA}_{2}$ are in strong correlations with $\mathrm{CEA}_{1}$, but compared to results of $\mathrm{CEA}_{1}$ the results of $\mathrm{CEA}_{2}$ have stronger correlation with $\mathrm{CEA}_{3}$, if taking into account the sample of all municipalities from the SMR.

The amount of solid municipal waste criterion is a generally recommended indicator for measuring efficiency of MSWE, see for instance [1], [9-11], [27], [29] and [32]. This makes the results of our analysis and the optimization of the decision making process of municipal administration using CEA even more interesting, as the most suitable criterion seems to actually be population. This criterion can be recommended for two more reasons - it has a very significant relationship with the amount of solid municipal waste verified by many analyses (e.g. [4], [14-15], [27]), and the criterion is easy to acquire from open linked data [2], [25], [31] databases and generally available for all municipalities and public.

\section{Conclusion}

Managing the information resources in decision making processes is one of the most prominent challenges of the public sector. Better methodology and internal information management create opportunities for innovation in reducing bureaucracy and diminishing administrative costs. Local governments (municipalities) face the complexities of uncertain and evolving environment protection, including external constraints such as the changing legal framework or the evaluation of public expenditure, especially in municipal waste management. Using linked open government data in current economic theory (CEA) together with advanced ICT brings new ideas in decision support for public administration about MSWE efficiency that allow decision makers to create benchmarks for municipalities in a given region.

The completed results of the paper:

- designed an appropriate methodology for rating the cost-effectiveness of MSWE, which was implemented with the use of ICT tools;

- concluded that in similar communities (ORPs) it is possible to use any of the selected three criteria and the evaluation results (order) are similar (very distinctive colinearity);

- from the perspective of different municipalities and in terms of benchmarks, the best metric to use is per capita expenditure.

Acknowledgements. This paper elaborates one of the findings of the specific research project MUNI/A/0786/2012 "Quality evaluation of public policies in the context of restrictive constraints of public finances". The authors express their gratitude to CENIA for providing data on waste generation. 


\section{References}

1. Anderson, W.: Economic analysis and cost-effectiveness analysis of proposed effluent limitations guidelines and standards for industrial waste combustors. US Environmental Protection Agency, Washington, DC (1998)

2. ARIS- Automatized budget information system, http://wwwinfo.mfcr.cz/aris/

3. Bakoš, E., Soukopová, J., Kaplanová, B.: Porovnání vykazovaných environmentálních dat se zaměřením na úroveň municipalit. In: Účetnictví a reporting udržitelného rozvoje na mikroekonomické a makroekonomické úrovni, pp. 79-85. Linde nakladatelstv dí Praha, Praha (2009)

4. Berger, C., Savard, G., Wisere, A.: EUGENE: An Optimisation Model for Integrated Regional Solid Waste Management Planning. Int. J. Environ. Pollut. 12, 280-307 (1999)

5. Boardman, A.E.: Cost-benefit analysis: concepts and practice. Prentice Hall, Upper Saddle River (2001)

6. Drummond, M.F., O`Brian, B., Stoddart, G., Torrance, G.W.: Methods for the Economics Evaluation of Health Care Programmes. Oxford University Press, Oxford (2001)

7. Fiala, P., Šauer, P.: Household Waste Management: Municipality Behavior Analysis by DEA Method. In: Aktan, C., Savanas, F. (eds.) Selected Proceedings of the First International Conference on Social Sciences, pp. 149-165. Izmir, Birlesik Matbaacilik (2008)

8. Gander, W., Hřebíček, J.: Solving problems in scientific computing using Maple and MATLAB. Springer, Heidelberg (2004)

9. Goulder, L.H., Parry, I.W., Williams, R.C., Burtraw, D.: The cost-effectiveness of alternative instruments for environmental protection in a second-best setting. J. Public Econ. 72, 329-360 (1999)

10. Hamilton, J.T., Viscusi, W.K.: How costly is "clean"? An analysis of the benefits and costs of Superfund site remediations. J. Policy Anal. Manag. 18, 2-27 (1999)

11. Hirsch, W.: Cost functions of an urban government service: refuse collection. Rev. Econ. Stat. 47(1), 87-92 (1965)

12. Hodinka, M., Štencl, M., Hřebíček, J., Trenz, O.: Current trends of corporate performance reporting tools and methodology design of multifactor measurement of company overall performance. Acta Universitatis Agriculturae et Silviculturae Mendelianae Brunensis 60, 85-90 (2012)

13. Hřebíček, J.: Mathematical Modeling of Economic Phenomena with Maple. In: Ramík, J., Stavárek, D. (eds.) Proceedings of 30th International Conference Mathematical Methods in Economics, pp. 326-331. Silesian University, Karviná (2012)

14. Hřebíček, J., Kalina, J., Soukopová, J.: Integrated economic model of waste management: Case study for South Moravia region. Acta Universitatis Agriculturae et Silviculturae Mendelianae Brunensis 61, 913-918 (2013)

15. Chen, H.W., Chang, N.: Prediction Analysis of solid waste generation based on grey fuzzy dynamic modelling, Resources. Conserv Recycling 29, 1-18 (2000)

16. Information system of waste management, http://isoh.cenia.cz/groupisoh/

17. Jenkins, R.R.: The Economics of Solid Waste Reduction: The Impact of User Fees. Edward Elgar Press, Brookfield (1993)

18. Kinnaman, T.C.: The economics of residential solid waste management. Ashgate, Aldershot (2003)

19. Levin, H.M., McEwan, P.J.: Cost-effectiveness analysis: Methods and applications. Sage Publications, Inc., Thousand Oaks (2000) 
20. Malý, I.: Problém optimální alokace zdrojů ve zdravotnictví. Masarykova Univerzita, Brno (1993)

21. Mandl, U., et al.: The effectiveness and efficiency of public spending (No. 301). European Commission: Directorate General Economic and Monetary Affairs (2008)

22. Nemec, J., Merickova, B., Vitek, L.: Contracting-out at local government level: Theory and selected evidence from the Czech and Slovak Republics. Pub. Manag. Rev. 7, 637-647 (2005)

23. Nemec, J., Merickova, B., Ochrana, F.: Introducing benchmarking in the Czech Republic and Slovakia. Pub. Manag. Rev. 10, 673-684 (2008)

24. Papageorgiou, A., Barton, J.R., Karagiannidis, A.: Assessment of the greenhouse effect impact of technologies used for energy recovery from municipal waste: a case for England.

J. Environ. Manage. 90, 2999-3012 (2009)

25. RIS - Regional Information Service, http: / /www.risy.cz/en/

26. Shah, A. (ed.): Public Services Delivery. The World Bank, Washington (2005)

27. Soukopová, J., Malý, I.: Competitive environment in waste management and its impact on municipal expenditures. Acta Universitatis Agriculturae et Silviculturae Mendelianae Brunensis 4, 173-183 (2013)

28. Stevens, B.: Scale, market structure and cost of refuse collection. Rev. Econ. Stat. 60, 438-448 (1978)

29. Struk, M., Soukopová, J.: Efficiency of the current municipal waste expenditure methodology approach and its application. Acta Universitatis Agriculturae et Silviculturae Mendelianae Brunensis 59, 379-386 (2011)

30. Šauer, P., Dvořák, A., Lisa, A., Fiala, P.: A procedure for negotiating pollution reduction under information asymmetry. Surface water quality case. Environmental and Resource Economics 24, 103-119 (2003)

31. UFIS, http://wwwinfo.mfcr.cz/ufis/

32. Wheeler, W.: Cost-effectiveness analysis of effluent limitation guidelines and standards for the centralized waste treatment industry. US Environmental Protection Agency Washington, DC (1998)

33. Willan, A., Brigs, A.: Statistical analysis of cost-effectiveness data. John Wiley \& Sons, New York (2006)

34. Winkler, J.: Filozoficko-metodologická východiska. In: Malý, I., et al. (eds.) Vliv veřejného sektoru na efektivnost rozvoje regionů. Masarykova univerzita, Brno (2001) 